\title{
Enterococcus rivorum sp. nov., from water of pristine brooks
}

\author{
R. Maarit Niemi, ${ }^{1}$ Tuula Ollinkangas, ${ }^{1}$ Lars Paulin, ${ }^{2}$ Pavel Švec, ${ }^{3}$ \\ Peter Vandamme, ${ }^{4}$ Antti Karkman, ${ }^{5}$ Marcel Kosina ${ }^{3}$ \\ and Kristina Lindström ${ }^{5}$
}

Correspondence

R. Maarit Niemi maarit.niemi@ymparisto.fi

\author{
${ }^{1}$ Finnish Environment Institute, Ecosystem Change, PO Box 140, FI-00251 Helsinki, Finland \\ ${ }^{2}$ Institute of Biotechnology, University of Helsinki, PO Box 56, FI-00014 Helsinki, Finland \\ ${ }^{3}$ Masaryk University, Faculty of Science, Department of Experimental Biology, \\ Czech Collection of Microorganisms (CCM), Trrdého 14, Brno 60200, Czech Republic \\ ${ }^{4}$ Laboratory of Bacteriology, Ghent University, K. L. Ledeganckstraat 35, B-9000 Ghent, Belgium \\ ${ }^{5}$ Department of Food and Environmental Sciences, Division of Microbiology, University of Helsinki, \\ PO Box 56, FI-00014 Helsinki, Finland
}

The genus Enterococcus includes human and animal intestinal commensals, but also increasingly problematic pathogens (Švec \& Devriese, 2009). Enterococci have been used as faecal indicators in hygienic water analysis, but the common occurrence of isolates that remain unidentified has caused uncertainty in interpretation (Clausen et al., 1977). Recent developments in taxonomy (Švec \& Devriese, 2009) offer a better basis to reveal natural environments for

The GenBank/EMBL/DDBJ accession numbers for the sequences obtained in this study are detailed in Table S1.

A supplementary table and four supplementary figures are available with the online version of this paper. each species and to estimate the value of each species as an indicator of water contamination.

Morphological and physiological characteristics are used to confirm that isolates belong to the genus Enterococcus, but identification to the species level is often uncertain (Švec \& Devriese, 2009). Differentiation of Enterococcus species on the basis of 16S rRNA gene sequencing has not been clear enough for all the closely related strains that have been described. Recently, novel enterococcal species have been differentiated by using more variable gene fragments, namely the $\alpha$-subunit of ATP synthase (atpA) (Naser et al., 2005a) and phenylalanyl-tRNA synthase (pheS) (Švec et al., 2005). Whole-cell protein fingerprints, which reveal an 
array of primary expression products of protein-encoding genes, have proved to be efficient in the differentiation of Enterococcus species (Niemi et al., 1993; Carvalho et al., 2006; Švec \& Devriese, 2009).

The species composition of enterococci in pristine waters in Finland remained obscure even when water samples with faecal contamination yielded known species (Niemi et al., 1993). The aim of the present study was to clarify the taxonomic position of the previously unidentified pristine water enterococci, which formed $32 \%$ of pristine water isolates (the sole habitat detected) observed as whole-cell protein fingerprint cluster VII, which also displayed low maximum growth temperatures (Niemi et al., 1993), by $16 \mathrm{~S}$ rRNA, atpA and pheS sequencing and (GTG) ${ }_{5}$-PCR and whole-cell protein fingerprinting.

Enterococci were isolated from pristine water bodies (no human habitation, agriculture or industry in the catchment area) in Finland on KF Streptococcus agar (Difco) using incubation at $35 \pm 2{ }^{\circ} \mathrm{C}$ for $44 \pm 4 \mathrm{~h}$ and were characterized as described by Niemi et al. (1993) for the Skerman criteria (growth at 10 and $45{ }^{\circ} \mathrm{C}$, tolerance of $6.5 \% \mathrm{NaCl}$ and $\mathrm{K}_{2} \mathrm{TeO}_{3}$, tolerance of $60{ }^{\circ} \mathrm{C}$ for $30 \mathrm{~min}$ ) according to Facklam \& Wilkinson (1981), for other physiological traits (API 50CHS), the presence of D antigen and for maximum growth temperature. Inocula and cell biomass were cultivated in brain heart infusion (BHI) broth (Difco), yielding good growth at $35-37{ }^{\circ} \mathrm{C}$ overnight. Isolates were stored in skimmed milk tubes at $-70{ }^{\circ} \mathrm{C}$. Analysed strains isolated from a brook from Pond Kilpilammi (WGS84lat 6051.44 and WGS84long 2401.31), S298, S299 and S309, and from a brook from Pond Vaunulammi (WGS84lat 6046.26 and WGS84long 2404.68), S259, S262, S271 and S280, are listed in Table S1 (available in IJSEM Online) together with the type strains subjected to sequencing in the present study. Reference Enterococcus species type strains, including that of the type species of the genus Enterococcus faecalis $\left(\mathrm{CCM} 7000^{\mathrm{T}}=\mathrm{DSM} 20478^{\mathrm{T}}\right)$, that were included in individual experiments were obtained from the BCCM/LMG (http://bccm.belspo.be/about/lmg. php) and CCM (http://www.sci.muni.cz/ccm/) bacteria collections.

DNA was isolated from bacterial cells using a Fast DNA kit and FastPrep Instrument (Q-BIOgene) according to the manufacturer's instructions but with an additional enzymic pretreatment: the pellet of cells was suspended in a mixture of $100 \mu \mathrm{l}$ phosphate buffer, $3 \mu \mathrm{l}$ lysozyme solution (1000 $\mathrm{U}$ in $1 \mathrm{ml}$ phosphate buffer) and $2.2 \mu \mathrm{l}$ mutanolysin solution $(5000 \mathrm{U}$ in $1 \mathrm{ml}$ buffer at $\mathrm{pH} 6.2$ containing $0.1 \mathrm{~mol} \mathrm{KH}_{2} \mathrm{PO}_{4} \mathrm{l}^{-1}$ ) and incubated for $45 \mathrm{~min}$ at room temperature.

A sequence of about $1585 \mathrm{bp}$ of the 16S rRNA gene was amplified as described by Weisburg et al. (1991) using the forward primer $\mathrm{fD} 1$ (5'-CCGAATTCGTCGACAACAGAGTTTGATCCTGGCTCA-3') and reverse primer $\mathrm{rD1}\left(5^{\prime}-\right.$ CCCGGGATCCAAGCTTAAGGAGGTGATCCAGCC- $3^{\prime}$ ). A $1102 \mathrm{bp}$ fragment of the atpA gene (encoding the $\alpha$-subunit of ATP synthase) was amplified using primers atpA-20-F, atpA-22-F, atpA-23-R, atpA-24-F, atpA-25-R and atpA-27-R according to Naser et al. (2005a). A 455 bp fragment of the pheS gene (encoding phenylalanyltRNA synthase) was amplified using primers pheS-21-F, pheS-22-R and pheS-23-R according to Švec et al. (2005). In addition to our environmental isolates, the type strains of Enterococcus caccae, E. camelliae, E. devriesei, E. silesiacus, E. termitis and E. thailandicus were sequenced for the atpA and pheS genes (Table S1).

The amplified fragments were purified using a Montage PCR Cleanup kit. Sequencing reactions were done with both forward and reverse primers using BigDye Chemistry and the reactions were analysed on an ABI 3130 DNA Sequencer. In addition, for sequencing of the $16 \mathrm{~S}$ rRNA gene, internal primers $\mathrm{pC}, \mathrm{pC}^{\prime}, \mathrm{pD}, \mathrm{pD}^{\prime}, \mathrm{pE}^{\prime}$ and $\mathrm{pF}$ were used (Edwards et al., 1989). For strain S271, two amplification products (fD1- $\mathrm{pE}^{\prime}$ and $\mathrm{pD}-\mathrm{rD} 1$ ) were produced for $16 \mathrm{~S}$ rRNA gene sequencing. The sequences obtained were edited and assembled using the Gap4 program from the Staden package (Staden et al., 2000).

BLASTN searches were run using version 2.2.24+ (http: //blast.ncbi.nlm.nih.gov/Blast.cgi) and the GenBank + $\mathrm{EMBL}+\mathrm{DDBJ}+\mathrm{PDB}$ sequence database. MAFFT version 6.8 (Katoh \& Toh, 2008) was used for sequence alignment of pheS and atpA. The Ribosomal Database Project aligner was used for the alignment of $16 \mathrm{~S}$ rRNA gene sequences (Cole et al., 2009). Alignments were edited manually and all unknown bases were removed from the analysis. Maximumlikelihood trees with 1000 bootstrap resamplings with branch lengths were drawn with RAxML version 7.0.3 (Stamatakis, 2006) on 16S rRNA gene sequences of about $1250 \mathrm{bp}$.

Repetitive sequence-based PCR fingerprinting with the $(\mathrm{GTG})_{5}$ primer was performed as described by Švec et al. (2008). Briefly, $1 \mu \mathrm{l}$ bacterial DNA isolated by an alkaline extraction procedure and $24 \mu \mathrm{l}$ PCR mixture were included in PCRs performed in a Tpersonal thermocycler using PCR conditions described previously (Švec et al., 2008). PCR products were separated in $1.5 \%$ agarose gels $(20 \times 20 \mathrm{~cm})$ for $16 \mathrm{~h}$ at $60 \mathrm{~V}$ (approx. $1.7 \mathrm{~V} \mathrm{~cm}^{-1}$ ) in $0.5 \times$ TBE buffer. Fingerprints were digitized and processed using the BioNumerics 6.5 software and compared to the in-house CCM database containing multiple reference strains covering all hitherto-described Enterococcus species. Numerical analysis of the (GTG) $)_{5}$-PCR fingerprints was conducted with Pearson's correlation coefficients and the resulting dendrogram was reconstructed using the UPGMA clustering method.

SDS-PAGE of whole-cell proteins was performed according to Pot et al. (1994). Cultures were grown at $37^{\circ} \mathrm{C}$ for $24 \mathrm{~h}$ on BHI agar. The cells were disrupted with a MagNA Lyser instrument. SigmaMarker Wide Range $(6.5-205 \mathrm{kDa})$ was used as a molecular mass marker set. Numerical analysis of digitized protein profiles was carried out with the BioNumerics 6.5 software using Pearson's correlation similarity 
coefficient. The dendrogram was reconstructed with the UPGMA clustering method.

The phylogenetic positions of the aquatic isolates were studied by the construction of maximum-likelihood trees with 1000 bootstrap resamplings with branch lengths based on 16S rRNA gene sequences of all the isolates and of all species of the genus Enterococcus, including the recently described species Enterococcus plantarum (Švec et al., 2012), E. ureasiticus and E. quebecensis (Sistek et al., 2012) (descriptions in press during preparation of this manuscript). On the basis of BLASTN searches, the most closely related sequences belonged to enterococci only. The five sequenced isolates formed a separate tight cluster within the E. faecalis genogroup (Švec \& Devriese, 2009), the closest species being E. faecalis $(98.74 \%$ similarity to the type strain); E. haemoperoxidus, E. moraviensis and E. quebecensis $(98.43 \%)$; E. plantarum $(98.35 \%)$; E. caccae and E. silesiacus (98.27\%); and E. termitis and E. ureasiticus $(98.19 \%)$ (see Fig. 1 for the E. faecalis genogroup; the whole tree is available as Fig. S1). Reciprocal DNA-DNA hybridizations were performed between strain $\mathrm{S} 299^{\mathrm{T}}$ and $E$. faecalis LMG $7937^{\mathrm{T}}$ according to a modification (Goris et al., 1998) of the microplate method described by Ezaki et al. (1989). DNA-DNA hybridization was $10.8 \pm 0.8 \%$ ( $E$. faecalis LMG $7937^{\mathrm{T}}$ as the probe) and $8.9 \pm 0.4 \%$ (strain $\mathrm{S} 299^{\mathrm{T}}$ as the probe) for four replicates, confirming that strain $\mathrm{S} 299^{\mathrm{T}}$ represents a novel species.

Sequencing of atpA confirmed the pristine water isolates as a tight separate cluster in the E. faecalis genogroup (Fig. S2a). pheS sequencing for the type strains of E. camelliae (excluded from the tree) and E. devriesei was possible only after purification of amplification products on gels due to the lack of specificity of the primers. The pheS sequencing

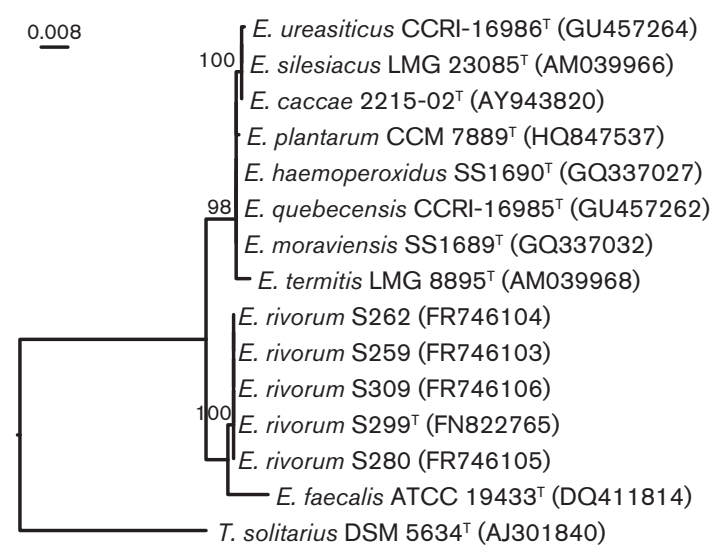

Fig. 1. Maximum-likelihood tree with branch lengths reconstructed on the basis of 16S rRNA gene sequences including strains belonging to the $E$. faecalis genogroup. Bootstrap values over $50 \%$ are given above branches. Tetragenococcus solitarius DSM $5634^{\top}$ was used as an outgroup. Bar, 0.008 substitutions per site. The full tree is shown in Fig. S1. confirmed the pristine water isolates as a separate tight cluster but, in accordance with Naser et al. (2005b), did not show phylogenetic relationships within the genus (Fig. S2b).

$(\mathrm{GTG})_{5}$-PCR fingerprinting was applied for seven of the pristine brook isolates together with the type strains of all described Enterococcus species. Numerical analysis of the fingerprints brought together all the environmental isolates into a well-separated cluster distinct from described species (Fig. S3).

The isolated strains formed a single homogeneous cluster with unique protein profiles that was clearly distinguished from the nearest phylogenetic neighbours (Fig. S4). The whole-cell protein profiles obtained from the analysed strains were visually nearly identical ( $85 \%$ similarity). Fig. S4 shows whole-cell protein fingerprints obtained from the environmental isolates and demonstrates their separation from the type strains of species of the E. faecalis group at a similarity level of $35 \%$. The data obtained showed clearly that all the investigated strains are representatives of a single species and confirmed their separation from their phylogenetically closest neighbours harboured in the $E$. faecalis species group.

The investigated isolates originated from two pristine brooks and, on the basis of their 16S rRNA gene sequences, they belong to a novel species in the E. faecalis genogroup. They also formed a separate cluster in both atpA and pheS sequence analyses. Their phenotypic characteristics are described below, and distinguishing characteristics within the E. faecalis genogroup are given in Table 1. The novel isolates differed from $E$. faecalis in being negative for hippurate hydrolysis and mostly also for lactose fermentation and positive for acid production from methyl $\alpha$-Dglucoside. They differed from E. caccae, E. haemoperoxidus and E. moraviensis in being tellurite tolerant. They differed from E. silesiacus in being positive for acid production from methyl $\alpha$-D-glucoside, mannitol, melezitose, sorbitol and sucrose. They differed from E. termitis in being positive for acid production from mannitol, melezitose and sucrose.

All the results shown above demonstrate that the analysed bacterial group represents a novel species within the genus Enterococcus. Phylogenetic analyses using 16S rRNA and atpA genes separated the studied group from all known enterococci, but clustered the investigated strains most closely to the type species of the genus, E. faecalis, which demonstrated clearly that the strains belong to the genus Enterococcus. Further investigations using phenotyping, whole-cell protein profiling, phes gene sequencing, (GTG) ${ }_{5}$-PCR fingerprinting and DNA-DNA hybridization confirmed these results and demonstrated clearly the separate position of the investigated strains with a specific habitat in the genus Enterococcus. On the basis of these results, a novel species is proposed for these distinct isolates. 
Table 1. Distinguishing characteristics of the novel strains and E. faecalis genogroup species

Strains/species: 1, S299 ${ }^{\mathrm{T}}$; 2, S259; 3, S262; 4, S271; 5, S280; 6, S298; 7, S309; 8, E. caccae (data from Carvalho et al., 2006); 9, E. silesiacus (Švec et al., 2006); 10, E. haemoperoxidus (Švec et al., 2001); 11, E. moraviensis (Švec et al., 2001); 12, E. termitis (Švec et al., 2006); 13, E. faecalis (Schleifer \& Kilpper-Bälz, 1984); 14, E. faecalis DSM $20478^{\mathrm{T}}$ (data from the present study). +, Positive; v, variation between strains; w, weak; d, delayed; - , negative; ND, no data available/not determined.

\begin{tabular}{|c|c|c|c|c|c|c|c|c|c|c|c|c|c|c|}
\hline Characteristic & 1 & 2 & 3 & 4 & 5 & 6 & 7 & 8 & 9 & 10 & 11 & 12 & 13 & 14 \\
\hline Group D antigen & - & - & - & + & - & + & + & + & $\mathrm{ND}$ & + & + & ND & + & ND \\
\hline Growth at $45{ }^{\circ} \mathrm{C}$ & - & $\mathrm{w}$ & $\mathrm{w}$ & $\mathrm{w}$ & $\mathrm{w}$ & - & - & + & - & - & - & + & + & + \\
\hline Tolerance of tellurite & + & + & + & + & + & + & + & - & $\mathrm{ND}$ & - & - & $\mathrm{ND}$ & + & + \\
\hline Growth in $6.5 \%(\mathrm{w} / \mathrm{v}) \mathrm{NaCl}$ & - & W & $\mathrm{W}$ & - & - & - & - & + & + & + & + & + & + & + \\
\hline Hydrolysis of hippurate & - & - & - & - & - & - & - & $\mathrm{V}$ & - & + & + & - & + & - \\
\hline Hydrolysis of arginine & - & - & - & + & - & - & - & - & + & $+/ \mathrm{d}$ & - & - & + & + \\
\hline Voges-Proskauer reaction & + & + & + & + & + & + & + & + & + & + & + & - & + & + \\
\hline \multicolumn{15}{|l|}{ Acid production from: } \\
\hline Methyl $\alpha$-D-glucoside & + & + & + & + & + & + & + & $\mathrm{ND}$ & - & + & + & + & - & - \\
\hline Methyl $\alpha$-D-mannoside & - & - & - & - & - & - & - & $\mathrm{ND}$ & - & - & - & + & - & - \\
\hline L-Arabinose & - & - & - & $\mathrm{w}$ & - & - & - & - & $\mathrm{v}$ & - & + & - & - & - \\
\hline Gluconate & - & - & - & $\mathrm{W}$ & - & - & - & $\mathrm{ND}$ & $\mathrm{v}$ & - & - & + & $\mathrm{V}$ & + \\
\hline Mannitol & + & + & + & + & + & + & + & - & - & $\mathrm{V}$ & + & - & + & + \\
\hline Sorbitol & + & + & + & + & + & + & + & - & - & - & - & ND & $\mathrm{V}$ & + \\
\hline Sucrose & + & + & + & + & + & + & + & + & - & + & + & - & + & + \\
\hline L-Xylose & - & - & - & $\mathrm{w}$ & - & - & - & ND & - & - & - & - & - & - \\
\hline
\end{tabular}

\section{Description of Enterococcus rivorum sp. nov.}

Enterococcus rivorum (ri.vo'rum. L. gen. pl. n. rivorum of brooks).

Cells are ovoid and Gram-stain-positive and occur singly or in pairs or chains. Non-spore-forming. White colonies are formed on BHI agar at $35{ }^{\circ} \mathrm{C}$. Strains are facultatively anaerobic and catalase-negative. Growth in broth containing $6.5 \% \mathrm{NaCl}$ and at $45{ }^{\circ} \mathrm{C}$ is weak or absent and production of $\mathrm{D}$ antigen is variable. The maximum temperature for growth on KF Streptococcus agar is 36.5$39.6{ }^{\circ} \mathrm{C}$. Strains tolerate $60{ }^{\circ} \mathrm{C}$ for $30 \mathrm{~min}$, tolerate $40 \%$ bile, tolerate and reduce tellurite, hydrolyse aesculin strongly and gelatin weakly and produce no acid from hippurate and do not reduce it. Generally weak growth occurs at $10{ }^{\circ} \mathrm{C}$. Strains exhibit a strong positive reaction for acid production from $\mathrm{N}$-acetylglucosamine and the Voges-Proskauer test and produce acid from glycerol, ribose, galactose, D-glucose, Dfructose, D-mannose, mannitol, sorbitol, methyl $\alpha$-D-glucoside, amygdalin, arbutin, aesculin (API $50 \mathrm{CHS}$ ), salicin, cellobiose, maltose, sucrose, trehalose, starch and gentiobiose. Variable for hydrolysis of arginine and variable production of acid occurs from D-xylose, inositol, lactose, melezitose, xylitol, turanose, D-lyxose, D-tagatose and Darabitol. Strains display weak or no production of acid from D- and L-arabinose, L-xylose, gluconate and 5-ketogluconate and produce no acid from erythritol, adonitol, methyl $\beta$ xyloside, L-sorbose, rhamnose, dulcitol, methyl $\alpha$-D-mannoside, melibiose, inulin, raffinose, glycogen, D- or L-fucose, L-arabitol or 2-ketogluconate.

The type strain, S299 ${ }^{\mathrm{T}}$ (=HAMBI $3055^{\mathrm{T}}=\mathrm{LMG} 25899^{\mathrm{T}}$ $=\mathrm{CCM} 7986^{\mathrm{T}}$ ), was isolated by one of the authors
(R. M. N.) from a pristine brook in Finland in 1990. It is positive for acid production from D-xylose, weakly positive for acid production from inositol, melezitose and turanose and negative for production of $\mathrm{D}$ antigen and acid production from lactose, xylitol, D-lyxose, D-tagatose and D-arabitol.

\section{Acknowledgements}

Our thanks are due to Riitta Vainio for her advice in naming the novel species, to the curators Claudine Vereecke of the LMG and Pekka Oivanen of the HAMBI culture collection and Ritta Saastamoinen for support with cultures and to Michael Bailey for correction of the language. We are grateful to Päivi Laamanen and Paula Collin-Olkkonen for excellent help in sequencing and Seija Turunen for designing of figures. Financial support from the Ministry of Education, Youth and Sports of the Czech Republic (project MSM0021622416) is acknowledged.

\section{References}

Carvalho, M. G., Shewmaker, P. L., Steigerwalt, A. G., Morey, R. E., Sampson, A. J., Joyce, K., Barrett, T. J., Teixeira, L. M. \& Facklam, R. R. (2006). Enterococcus caccae sp. nov., isolated from human stools. Int J Syst Evol Microbiol 56, 1505-1508.

Clausen, E. M., Green, B. L. \& Litsky, W. (1977). Fecal streptococci: indicators of pollution. In Bacterial Indicators/Health Hazards Associated with Water (ASTM Publication 635), pp. 247-264. Edited by A. W. Hoadley \& B. J. Dutka. Philadelphia: American Society for Testing and Materials.

Cole, J. R., Wang, Q., Cardenas, E., Fish, J., Chai, B., Farris, R. J., KulamSyed-Mohideen, A. S., McGarrell, D. M., Marsh, T. \& other authors (2009). The Ribosomal Database Project: improved alignments and new tools for rRNA analysis. Nucleic Acids Res 37, D141-D145. 
Edwards, U., Rogall, T., Blöcker, H., Emde, M. \& Böttger, E. C. (1989). Isolation and direct complete nucleotide determination of entire genes. Characterization of a gene coding for $16 \mathrm{~S}$ ribosomal RNA. Nucleic Acids Res 17, 7843-7853.

Ezaki, T., Hashimoto, Y. \& Yabuuchi, E. (1989). Fluorometric deoxyribonucleic acid-deoxyribonucleic acid hybridization in microdilution wells as an alternative to membrane filter hybridization in which radioisotopes are used to determine genetic relatedness among bacterial strains. Int J Syst Bacteriol 39, 224-229.

Facklam, R. \& Wilkinson, W. (1981). The family Streptococcaceae (medical aspects). In The Prokaryotes, pp. 1572-1597. Edited by M. P. Starr, H. Stolp, H. G. Trüper, A. Balows \& H. G. Schlegel. Berlin: Springer.

Goris, J., Suzuki, K., De Vos, P., Nakase, T. \& Kersters, K. (1998). Evaluation of a microplate DNA-DNA hybridization method compared with the initial renaturation method. Can J Microbiol 44, 1148-1153.

Katoh, K. \& Toh, H. (2008). Recent developments in the MAFFT multiple sequence alignment program. Brief Bioinform 9, 286-298.

Naser, S., Thompson, F. L., Hoste, B., Gevers, D., Vandemeulebroecke, K., Cleenwerck, I., Thompson, C. C., Vancanneyt, M. \& Swings, J. (2005a). Phylogeny and identification of enterococci by atpA gene sequence analysis. J Clin Microbiol 43, 2224-2230.

Naser, S. M., Thompson, F. L., Hoste, B., Gevers, D., Dawyndt, P., Vancanneyt, M. \& Swings, J. (2005b). Application of multilocus sequence analysis (MLSA) for rapid identification of Enterococcus species based on rpoA and pheS genes. Microbiology 151, 2141-2150.

Niemi, R. M., Niemelä, S. I., Bamford, D. H., Hantula, J., Hyvärinen, T., Forsten, T. \& Raateland, A. (1993). Presumptive fecal streptococci in environmental samples characterized by one-dimensional sodium dodecyl sulfate-polyacrylamide gel electrophoresis. Appl Environ Microbiol 59, 2190-2196.

Pot, B., Vandamme, P. \& Kersters, K. (1994). Analysis of electrophoretic whole-organism protein fingerprints. In Modern Microbiological Methods: Chemical Methods in Prokaryotic Systematics, pp. 493-521. Edited by M. Goodfellow \& A. G. O’Donnell. Chichester: Wiley.

Schleifer, K. H. \& Kilpper-Bälz, R. (1984). Transfer of Streptococcus faecalis and Streptococcus faecium to the genus Enterococcus nom. rev. as Enterococcus faecalis comb. nov. and Enterococcus faecium comb. nov. Int J Syst Bacteriol 34, 31-34.

Sistek, V., Maheux, A. F., Boissinot, M., Bernard, K. A., Cantin, P., Cleenwerck, I., De Vos, P. \& Bergeron, M. G. (2012). Enterococcus ureasiticus sp. nov. and Enterococcus quebecensis sp. nov., isolated from water. Int J Syst Evol Microbiol 62, 1314-1320.

Staden, R., Beal, K. F. \& Bonfield, J. K. (2000). The Staden package, 1998. Methods Mol Biol 132, 115-130.

Stamatakis, A. (2006). RAxML-VI-HPC: maximum likelihood-based phylogenetic analyses with thousands of taxa and mixed models. Bioinformatics 22, 2688-2690.

Švec, P. \& Devriese, L. A. (2009). Genus I. Enterococcus (ex Thiercelin and Jouhaud 1903) Schleifer and Kilpper-Bälz 1984, 32 ${ }^{\mathrm{VP}}$. In Bergey's Manual of Systematic Bacteriology, 2nd edn, vol. 3, pp. 594-607. Edited by P. De Vos, G. M. Garrity, D. Jones, N. R. Krieg, W. Ludwig, F. A. Rainey, K. H. Schleifer \& W. B. Whitman. New York: Springer.

Švec, P., Devriese, L. A., Sedláček, I., Baele, M., Vancanneyt, M., Haesebrouck, F., Swings, J. \& Doškař, J. (2001). Enterococcus haemoperoxidus sp. nov. and Enterococcus moraviensis sp. nov., isolated from water. Int J Syst Evol Microbiol 51, 1567-1574.

Švec, P., Vancanneyt, M., Devriese, L. A., Naser, S. M., Snauwaert, C., Lefebvre, K., Hoste, B. \& Swings, J. (2005). Enterococcus aquimarinus sp. nov., isolated from sea water. Int J Syst Evol Microbiol 55, 21832187.

Švec, P., Vancanneyt, M., Sedláček, I., Naser, S. M., Snauwaert, C., Lefebvre, K., Hoste, B. \& Swings, J. (2006). Enterococcus silesiacus sp. nov. and Enterococcus termitis sp. nov. Int J Syst Evol Microbiol 56, 577-581.

Švec, P., Nováková, D., Zácková, L., Kukletová, M. \& Sedláček, I. (2008). Evaluation of (GTG) $)_{5}$-PCR for rapid identification of Streptococcus mutans. Antonie van Leeuwenhoek 94, 573-579.

Švec, P., Vandamme, P., Bryndová, H., Holochová, P., Kosina, M., Mašlaňová, I. \& Sedláček, I. (2012). Enterococcus plantarum sp. nov., isolated from plants. Int J Syst Evol Microbiol 62, 1499-1505.

Weisburg, W. G., Barns, S. M., Pelletier, D. A. \& Lane, D. J. (1991). $16 \mathrm{~S}$ ribosomal DNA amplification for phylogenetic study. J Bacteriol 173, 697-703. 